\title{
PINTURA E LITERATURA EM MERLEAU-PONTY: EXPRESSÃO DIACRÍTICA E INSTITUIÇÃO HISTÓRICA
}

\author{
PEINTURE ET LITTÉRATURE CHEZ MERLEAU-PONTY: EXPRESSION DIACRITIQUE ET INSTITUTION \\ HISTORIQUE
}

Iracy Ferreira dos Santos Júnior*

\begin{abstract}
RESUMO
A partir do contato com as obras do período intermediário do pensamento de Merleau-Ponty (1948-1955), este artigo pretende demonstrar como pintura e literatura, enquanto formas de expressão, revelam-se capazes de reaprender a ver o mundo, de apreender o sentido do mundo ou da história em estado nascente, sem jamais esgotar esse sentido. Para isso, descreve como Merleau-Ponty amplia o sentido da noção de diacriticidade, de Saussure, ao não limitá-la à análise linguística da linguagem, mas ao admitir que tanto a percepção quanto a expressão e o próprio sensível partilham uma função diacrítica. Em seguida, tomando a pintura como linguagem, analisa como, por meio da noção de estilo, pintor e escritor, cada um a seu modo, "deformam" a linguagem e a tradição instituídas para fazer surgir nelas uma nova linguagem. Por fim, elucida a matriz temporal e histórica do conceito de instituição ao apresentar o modo como a obra de arte pictórica ou literária opera uma retomada dessa tradição e institui um novo sentido na história como advento, presença, abertura inesgotável.
\end{abstract}

PALAVRAS-CHAVE: Merleau-Ponty. Expressão diacrítica. Pintura. Literatura. Instituição histórica.

\section{RÉSUMÉ}

À partir du contact avec les œuvres de la période intermédiaire de la pensée de Merleau-Ponty (1948-1955), cet article vise démontrer comment la peinture et la littérature, en tant que formes d'expression, se révèlent capables de réapprendre à voir le monde, de saisir le sens du monde ou de l'histoire dans son état naissant, sans jamais puiser le sens. Pour cela, il décrit comment Merleau-Ponty élargit le sens de la notion de diacriticité, de Saussure, en ne la limitant pas à l'analyse linguistique de la langue, mais en admettant que la perception et l'expression, ainsi que le sensible lui-même, partagent une fonction diacritique. Puis, en prenant la peinture comme langage, il analyse comment, par la notion de style, peintre et écrivain, chacun à sa façon, « déforment» le langage et la tradition institués pour y faire apparaître un nouveau langage. En dernier, il élucide la matrice temporelle et historique du concept d'institution en présentant la façon dont l'œuvre d'art pictural ou littéraire opère une reprise de cette tradition et institue un nouveau sens dans l'histoire en tant qu'avènement, présence et ouverture inépuisable.

MOTS-CLÉS: Merleau-Ponty. Expression diacritique. Peinture. Littérature. Institution historique.

\footnotetext{
*Doutorando em Filosofia pela Universidade de São Paulo (USP). E-mail: jrgbi@usp.br.
} 


\section{A EXIGÊNCIA DA EXPRESSÃo}

No prefácio da Fenomenologia da percepção, Merleau-Ponty apresenta a fenomenologia como uma tentativa de reaprender a ver o mundo, como um método para se despir das "prévisões" preconizadas pela tradição filosófica. Se a fenomenologia tem a tarefa de revelar o mistério do mundo e o mistério da razão, a pintura e a literatura têm a laboriosa tarefa de abrigar o "mesmo gênero de atenção e admiração" perante o mundo e possuem a "mesma vontade de apreender o sentido do mundo ou da história em estado nascente" (MERLEAU-PONTY, 2015a, p. 20). Assim, pintura, romance, poesia seriam diferentes formas de expressão que se mostram como modos de reaprender a ver o mundo, como criações originais que retornam ao originário e dele se aproximam sem jamais esgotá-lo. Quer dizer, trata-se de retomar uma vertente subterrânea do mundo - modo como as coisas apelam à arte enquanto presença alusiva, indireta - , de um "pré-mundo", um mundo sem familiaridade, que as artes picturais e linguísticas são capazes de expressar. Trata-se de uma dimensão do mundo que não pertence aos sujeitos, porque não foi constituída por eles, mas que, todavia, somente o sujeito é capaz de desvendar esse pré-mundo inumano sobre o qual sua existência está instalada (CARBONE, 2001, p. 25).

Merleau-Ponty sublinha, ao longo de sua obra, a importância da relação ou cumplicidade primordial com o mundo e a irredutibilidade dessa experiência concreta, originária, através da necessidade de um retorno ao fenômeno pela percepção, ao modo como ele aparece não tematizado pela consciência constituinte. Para ele, é preciso "ater-se à experiência muda do mundo operada pelo corpo, a fim de conduzi-la à expressão pura de seu próprio sentido" (MERLEAU-PONTY, 2015a, p. 12) ${ }^{1}$. Aqui, nessa máxima profundamente estudada, surge a exigência da expressão para o filósofo, pois esse retorno só é possível graças à inserção corporal do sujeito num mundo que o afeta sensível e constantemente. É essa inserção no sensível pela encarnação do sujeito que a filosofia deve explicitar através da expressão, cujos meios lhe são

\footnotetext{
${ }^{1}$ Essa emblemática frase está presente nas Meditações cartesianas de Husserl e é citada por Merleau-Ponty como um refrão. Em uma discussão com De Waelhens, em 1959, Merleau-Ponty comenta-a afirmando que o postulado de Husserl atribui à fenomenologia uma tarefa difícil, quase impossível, pois o que se esboça entre o silêncio das coisas e a fala filosófica não é uma espécie de acordo ou de harmonia preestabelecida, e sim uma dificuldade, uma tensão. Se a experiência fosse inteiramente muda, ela jamais atingiria seu sentido próprio: seu sentido seria imposto do exterior, haveria apenas falas sobre a experiência, mas não falas surgindo das profundidades da própria experiência. Por outro lado, se a experiência fosse eloquente por si-mesma, a fala diria nada mais do que já foi dito. Ou as coisas não diriam nada ou diriam tudo. E a fenomenologia tende a se aproximar mais da segunda, no que permanece o caráter ambíguo tanto do primeiro Husserl, quanto do primeiro Merleau-Ponty sobre esse ponto (WALDENFELS, 1999, p. 58).
} 
mais familiares, porque toda percepção, toda ação que a supõe, todo uso humano do corpo já é expressão primordial ${ }^{2}$ (MERLEAU-PONTY, 1991, p. 70).

Nos escritos após a Fenomenologia da percepção, Merleau-Ponty busca oferecer uma teoria da expressão e, diante dessa exigência, ele manterá diálogo com as artes mudas (pintura) e de linguagem (literatura), porque elas se revelam como caminho de retorno ao logos do mundo estético - fundo comum de toda criação para tentar exprimi-lo utilizando de seus recursos possíveis - para reencontrar "este contato ingênuo com o mundo para lhe dar, enfim, um estatuto filosófico" (MERLEAU-PONTY, 2015a, p. 1). Para o autor, uma obra de arte pictórica ou literária fornece emblemas cujos sentidos jamais se desenvolvem plenamente, pois ela se instala e instala o sujeito num mundo do qual não se tem a chave, descentra sua visão de mundo e o ensina a ver e o faz pensar como nenhuma obra analítica pode fazê-lo (MERLEAU-PONTY, 2012, p. 156-157).

Toda expressão jamais se separa da situação corporal, já que todo uso humano que se faz do corpo é uma expressão primordial. É próprio do gesto humano significar, quer dizer, o gesto perceptivo inaugura um sentido, instaura uma orientação onde antes ela não existia. Cada gesto perceptivo ou linguístico é um começo, anuncia uma sequência ou recomeço e se revela de antemão "aliado ou cúmplice de todas as outras tentativas de expressão" (MERLEAU-PONTY, 1991, p. 71), uma vez que ele introduz um sentido. A partir daí, pode Merleau-Ponty afirmar que "o campo das significações está aberto desde que surgiu um homem no mundo", pois, com o primeiro rabisco ou a primeira palavra, o sujeito abriu uma tradição, uma vez que é a própria “operação expressiva do seu corpo, iniciada pela menor percepção, que se amplifica em pintura e em arte" (p. 73).

Assim, ao visar o retorno ao sensível para expressá-lo, o artista ou o escritor torna explícito o logos implícito que se desenha no mundo estético, perceptivo. Trata-se, nesse caso, de retomá-lo e metamorfoseá-lo em obras de arte no mundo cultural, metamorfose do sentido latente da percepção em sentido manifesto na ordem da expressão. Daí surge um envolvimento entre experiência perceptiva e expressão no qual se solicitam reciprocamente num mesmo movimento,

\footnotetext{
2 A noção de expressão em Merleau-Ponty ganha força no período intermediário de seu pensamento (19481955), uma vez que seu uso nos textos anteriores a 1952 estava ligado a uma retomada discursiva da experiência perceptiva. Essa articulação entre percepção e expressão é evidenciada no curso Le monde sensible et le monde de l'expression (1952-1953), "no qual seu duplo objetivo é: 1) aprofundar a análise do mundo percebido mostrando que ele supõe já a função expressiva; 2) preparar a análise dessa função pela qual o mundo percebido é sublimado, faz uma teoria concreta do espírito" (MERLEAU-PONTY, 2011, p. 45, tradução nossa).
} 
consolidando a espontaneidade da expressão fundada no nível perceptivo numa constante relação ${ }^{3}$.

O próprio Merleau-Ponty (2012, p. 75) admite que exprimir-se é um empreendimento paradoxal, "uma vez que supõe um fundo de expressões aparentadas, já estabelecidas, e que sobre esse fundo a forma empregada se destaque, permaneça suficientemente nova para chamar a atenção". Ou seja, o que se fala cotidianamente de maneira corriqueira, repetindo signos já estabelecidos, contém implicitamente o paradoxo presente na criação de novas formas de expressão, pois nelas está sempre a possibilidade de uma novidade linguística. Além disso, elas são suficientes para uma comunicação com outrem, como é o caso das significações artísticas que, mesmo faladas e conservadas como aquisição cultural, mostram-se sempre pregnantes de sentido e dependentes de retomadas dessas aquisições operadas pelo escritor ou pintor. Por outro lado, essa possibilidade não torna a expressão definitiva, pois ela tende sempre à sua destruição, apagase à medida que se propaga e entrega o sentido sem ter que pensar nos signos linguísticos da frase, fazendo dela uma atividade bem-sucedida.

A ideia de uma expressão completa é vazia de sentido, assim como a ideia de uma linguagem direta, capaz de dizer a essência das coisas. Num movimento contrário, Merleau-Ponty avança pelo caminho da expressão indireta, alusiva, e sabe que ela contém, em seu caráter inesgotável, o segredo da infinidade das formas da cultura. Assim, concentrar-se nesse modo de expressão indireto é ver sua diacriticidade, sua lacuna, seu desvio; é lançar-se no terreno da linguagem falante, da escrita literária, no qual a relação entre palavra e silêncio tem na literatura sua eterna celebração.

Apresentada a exigência da expressão no filósofo francês, doravante, a partir de textos do período intermediário do pensamento de Merleau-Ponty (1948-1955), pretende-se dilucidar a expressão a partir da análise das artes mudas e de linguagem (com mais ênfase na literatura); evidenciar como Merleau-Ponty se utiliza da análise linguística da linguagem, em Saussure, para construir sua teoria da expressão e como essas formas de expressão partilham uma função "diacrítica"; ver a pintura, enquanto voz do silêncio, em paralelo com a literatura, cujas atividades

\footnotetext{
3 "No pensamento de Merleau-Ponty, enquanto, em um primeiro momento, o estudo da expressão se efetua a partir do quadro teórico estabelecido no nível da percepção, pouco a pouco, segundo um movimento regressivo, o sentido do mundo percebido se encontrará retomado a partir do fenômeno da expressão." (BARBARAS, 1998, p. 191, tradução nossa).
} 
são compreendidas como "expressão criadora", e como elas instituem um sentido sempre aberto na história e na cultura.

\section{A PINTURA COMO LINGUAGEM DIACRÍTICA: VOZ DO SILÊNCIO}

Nos anos que seguiram a publicação da Fenomenologia da percepção (1945), a concepção de linguagem em Merleau-Ponty foi transformada pela "descoberta" da obra de Saussure, que tinha como tese central a relação diacrítica entre signo e significação, na qual a positividade dos signos emerge apenas da diferença instaurada na relação entre eles. Tomados isoladamente, os signos nada significam. A significação transcende sempre os signos separados. O signo é de imediato diacrítico, compõe-se e se organiza consigo mesmo, possui um interior e, por isso, reclama um sentido. Esse sentido diacrítico nasce na borda dos signos, na relação lateral que eles exercem entre si, enquanto "unidade de coexistência"; o sentido se cria somente na relação entre os termos linguísticos; e, portanto, na língua, não há senão diferenças de significação (MERLEAU-PONTY, 1991, p. 39-41, passim). Lendo atentamente Saussure, Merleau-Ponty pôde ir além no desenvolvimento de sua própria fenomenologia da linguagem e ampliar a significação do conceito de "diacriticidade", entendido aqui como intervalo, desvio [écart]. Segundo Merleau-Ponty, a diacriticidade está na base de toda distinção e de toda diferença. A função "diacrítica" não se limita somente ao domínio linguístico ou da linguagem, mas se aplica igualmente à percepção, à expressão, ao próprio sensível, de modo que se pode afirmar que uma não existe sem a outra ${ }^{4}$.

No ensaio interrompido "A linguagem indireta e as vozes do silêncio", Merleau-Ponty mantém um importante diálogo com a obra Les voix du silence, de André Malraux, sobre a

\footnotetext{
4 "Perceber uma fisionomia, uma expressão, é usar sempre de signos diacríticos, do mesmo modo que realizar com seu corpo uma gesticulação expressiva." (MERLEAU-PONTY, 2011, p. 204, tradução nossa). Não se deve dizer somente que o signo linguístico é diacrítico, mas que todo sentido e, antes de tudo, o próprio sensível é diacrítico. "O valor diacrítico do sentido é uma das maneiras de pensar o nada no ser contra toda ontologia do objeto, contra toda ontologia positiva. O estudo vigilante e preciso da linguística, de Saussure em particular, vem confirmar as descrições da percepção em termos de desvios e diferenças; vem também acentuar o traço por fazer da dimensão diacrítica do sentido como uma das características essenciais do Ser.” (ROBERT, 2020, p. 248, tradução nossa).

${ }^{5}$ Em 1952 Merleau-Ponty extrai o ensaio "A linguagem indireta e as vozes do silêncio" de sua obra interrompida A prosa do mundo - publicada postumamente - e o publica na resvista Les temps modernes. Nesse ensaio, ele trata da linguagem e da pintura em diálogo com o trabalho de André Malraux. Outro ponto importante que motiva Merleau-Ponty é a publicação do ensaio de Sartre "O que é a literatura?", em 1948, que lhe causou uma profunda impressão e o confirmou em seu propósito de tratar dos problemas da expressão da literatura. Tanto
} 
questão da arte como caso particular de linguagem para demonstrar, nesse primeiro momento, como a pintura fala à sua maneira e seu sentido diacrítico emerge, como sua voz é feita de cores e traços: "voz do silêncio". Para Merleau-Ponty, na pintura, a noção de diacriticidade é evocada porque as cores e os traços, assim como os signos linguísticos, formam um todo significativo e harmônico, e adquire seu sentido próprio através da articulação interna ou pela diferenciação mútua entre eles, isto é, a pintura fala diacriticamente como voz do silêncio.

Para explicar esse modo diacrítico de a pintura exprimir-se, Merleau-Ponty equipara a atividade do pintor à do escritor. $\mathrm{O}$ ato de pintar expõe duas faces (duas linguagens): "há o borrão ou o traço de cor que são colocados num ponto da tela, e há o efeito deles no conjunto, sem medida em comum com eles, já que não são quase nada e bastam para mudar um retrato ou uma paisagem" (MERLEAU-PONTY, 1991, p. 45). Uma face da pintura está contida nas pinceladas de tinta realizadas pelo pintor, o sedimentado da pintura, que fornece o avesso da obra como outra face, cuja possibilidade é a de um sentido sempre nascente, de fazer existir um quadro que ainda não existia, que surge como advento. A pintura dá a ver um nível anterior à denominação, "uma impressão imediata das coisas", oferece uma primeira visão das coisas e do mundo em estado nascente, em seu aparecer, e revela a experiência do nascimento das coisas no espectador, sua maneira de se dirigir a ele, na percepção, antes mesmo das palavras que as nomeiam. Por essa razão, o pintor se instala no mundo sedimentado da pintura para desvelar o seu avesso, o impensado que há no intervalo, no desvio entre uma pincelada e outra. Assim, a pintura metamorfoseia o mundo ao pintar o aparecer das coisas à visão, ela é "uma linguagem das coisas" (MERLEAU-PONTY, 2020, p. 150-153, passim, tradução nossa). Do mesmo modo, na literatura, a palavra expressiva do escritor não escolhe somente um signo para uma significação definida, ele trabalha pelo avesso: se instala num mundo falante, lida com a linguagem e logo se vê rodeado de sentido; "tateia em torno de uma intenção de significar que não se guia por um texto, o qual justamente está em vias de escrever” (MERLEAU-PONTY, 1991, p. 47).

O trabalho de ambos - pintor e escritor - se estabelece a partir de uma rede de objetos (formas, palavras, cores, sintaxes) de uso prosaico, pela qual ambos se apropriam dessa atmosfera comum de sentidos e a ressignificam, possibilitando novas obras expressivas. A partir dessas

que a versão final do ensaio "A linguagem indireta e as vozes do silêncio" será publicada na obra Signo em 1960, com uma dedicatória a Sartre, além de trazer as contribuições oferecidas pela linguística de Saussure, ausentes na primeira redação do texto. Isso porque Merleau-Ponty iniciara seu contato com a linguística para fundamentar sua análise sobre a linguagem literária. Este nosso artigo investiga e utiliza as duas versões desse ensaio. 
condições torna-se "possível considerar a pintura sobre o fundo da linguagem e a linguagem sobre o fundo da pintura" (MERLEAU-PONTY, 2012, p. 94).

$\mathrm{O}$ pintor comunica o sentido de sua obra quando consegue colocar no quadro não características de apurada técnica ou do bom gosto ou, ainda, as sutilezas de uma subjetividade adorada, mas quando consegue expressar seu estilo. Essa noção de estilo será central no pensamento sobre as artes em Merleau-Ponty. Ao contrário de um fim perseguido pelo artista ou de um meio de representar no qual o artista deixa suas marcas em seus quadros para ser reconhecido, o estilo é o conjunto dos meios pelos quais se faz aparecerem as coisas e os outros, pelo modo como organizam os elementos do mundo na própria experiência do pintor ou do escritor, ou seja, "é uma questão, não de técnica, mas de visão" (MERLEAU-PONTY, 2020, p. 181, tradução nossa). Diferentemente do gênio, o estilo não separa o artista do mundo, dos outros e de suas obras, dos acasos em meio aos quais elas nascem; antes de ser predileção para os outros, é preciso que o estilo germine de um momento fecundo na "superfície da experiência, em que um sentido operante e latente encontrou para si os emblemas que deveriam libertá-lo e torná-lo manejável pelo artista e ao mesmo tempo acessível aos outros" (MERLEAU-PONTY, 1991, p. 54).

O pintor não tem a obra em sua cabeça antes da execução, ela está difusa em sua vida de artista, esparsa no mundo e solicita o seu olhar. Sua vida está alastrada nas obras, e estas exercem um comércio com o mundo no qual o pintor habita. $\mathrm{O}$ estilo não surge tematizado na consciência do artista - como se fosse um "eu" afastado do mundo e dos outros - e tampouco é oriundo de determinada corrente artística, como se o pintor fosse rotulado por determinada escola de acordo com o "padrão" de técnicas aplicadas. Sem recuar a uma subjetividade (eu do pintor) ou a uma objetividade (definições da escola artística), o estilo, para Merleau-Ponty (2012, p. 109), "é o que torna possível toda significação", ele instaura um momento fecundo que propicia a emergência de sentidos criadores, no instante em que o pintor utiliza-se dos sentidos iminentes no mundo, transformando-os em obra.

Assim, objetividade e subjetividade não estão apartadas, mas se estabelecem numa tensão/relação em que o estilo, enquanto movimento operante e latente, "não é um meio de representar, o que seria supor-lhe um modelo exterior, [...] mas tampouco que a representação do mundo seja 'um meio do estilo', o que seria fazê-lo conhecido antecipadamente como um fim" (MERLEAU-PONTY, 2012, p. 111, grifos do autor). Na verdade, o estilo só pode ser conquistado a partir da vida empírica do pintor no mundo e só aparece a partir do contato entre 
ambos, "no côncavo de sua percepção de pintor e como uma exigência proveniente dela" (p. 111). Portanto, ele se faz desde o olhar do pintor, que atende aos apelos do mundo, estiliza-o através de sua visão, de seu sotaque, da maneira como manuseia o pincel, do jeito como habita o próprio corpo, da forma como "deforma" o mundo instituído da pintura para engendrar novas significações.

Mas como se dá esse processo de instauração de uma nova significação? Merleau-Ponty (2012, p. 110) diz que, para "compreender a origem da significação [...], precisamos aqui nos privar de toda significação já instituída e voltar à situação de partida de um mundo não significante que é sempre o do criador, pelo menos no que toca àquilo justamente que ele vai dizer". Com isso, o autor rejeita uma essência que contenha todos os significados possíveis num mundo inteligível aguardando para serem desvelados; rejeita também o fato de a significação se dar por um recuo ao mundo privado de um indivíduo, mas reconhece que ela aflora na relação que o homem (artista) entretém com o mundo, pois é expressiva, presentifica um sentido a partir das fissuras que há entre uma significação e outra ${ }^{6}$.

Por essa razão, o pintor faz convergir em sua percepção de mundo as significações ainda espalhadas nas coisas e as expressa no quadro, manifestando-as por meio de seu estilo. O estilo vem da percepção, reconhece Merleau-Ponty (2012, p. 112) ao afirmar o que Malraux disse sabiamente: “a percepção já estiliza". O estilo é, em cada pintor, "o sistema de equivalências que ele monta para essa obra de manifestação, o índice geral de 'deformação coerente' pela qual ele concentra a significação ainda esparsa em sua percepção e a faz existir expressamente" (MERLEAU-PONTY, 2012, p. 114). Sua expressão pictural recria e metamorfoseia o mundo, e essa sistematização do mundo na tela traz consigo uma nova possibilidade de articulação dos sentidos vigentes na cultura. O pintor, desse modo, como se verá mais à frente, retoma uma herança de significações e sentidos sedimentados e relança uma tradição que instaura novos horizontes, ou seja, "há significação quando submetemos os dados do mundo a uma 'deformação coerente"” (MERLEAU-PONTY, 2012, p. 113). Essa deformação é como um novo relevo artístico a partir da percepção que o artista tem do mundo.

\footnotetext{
${ }^{6} \mathrm{Na}$ criação dos novos sentidos, "é suficiente que, no pleno das coisas, introduzamos certos vazios, certas fissuras — e fazemos isso tão logo vivamos —, para fazer vir ao mundo precisamente aquilo que lhe é o mais estranho: um sentido, uma incitação irmã das que nos arrastam para o presente ou o futuro ou o passado, para o ser ou o não-ser" (MERLEAU-PONTY, 2012, p. 113, grifo do autor).
} 
São “deformações" porque os dados do mundo são apreendidos segundo a maneira como tocam a visão e se revelam na experiência e, entretanto, "coerentes" porque reenviam todas a uma significação única e visível que elas organizam; são as deformações que fazem com que haja significação, sentido. No contato com o mundo e com as coisas, a pintura se faz, ela solicita o olhar criador do pintor, expressando-se através do comércio que ele exerce com o mundo. Nesse comércio, o sentido expresso pela obra exige exatamente um arranjo, um "sistema de equivalências", pelo qual o sentido se faz emergir sempre, evocando uma maneira de se manifestar que permite comunicação e de se instituir em toda história da cultura. Esse sentido é sempre diacrítico porque aparece justamente no intervalo entre uma pincelada e outra, fazendo com que cada obra revele um mundo por ver, por dizer. Portanto, mais do que exprimir ou manifestar o sentido, a obra está impregnada dele.

Nessa perspectiva, ancorada nessa estrutura diacrítica da linguagem, espera-se agora mostrar que a literatura se exprime de maneira análoga à pintura, isto é, segundo o modo da percepção e se revela capaz de produzir um sentido inédito, diacrítico. Em outras palavras, demonstrar-se-á que a escrita literária é uma operação poética que não é diferente daquela do pintor, ou seja, ela exprime tanto pelo que está entre as palavras quanto pelas próprias palavras, pelo dito e pelo não dito. No entanto, não se pretende comparar os modos de expressão, uma vez que Merleau-Ponty afirma que eles não são iguais, mas mostrar que estão alicerçados na diacriticidade. Trata-se, doravante, de ver como a palavra literária se revela enquanto criação expressiva e ver como o escritor "deforma" a linguagem habitual para fazer surgir nela mesma uma linguagem falante, da literatura, que parece ter um lugar de destaque no pensamento de Merleau-Ponty porque mostra mais ostensivamente como a expressão ultrapassa a oposição do interior e do exterior, instala o leitor no tempo e, através do evento do discurso, da fala, "instaura e restaura um 'Logos' do mundo cultural” (MERLEAU-PONTY, 1991, p. 103).

\section{A LITERATURA COMO CRIAÇÃO EXPRESSIVA}

Pensada no interior da distinção entre linguagem falada e linguagem falante, entre o uso empírico e o criador $^{7}$, a literatura tem como atributo essencial a capacidade de criação de um

\footnotetext{
${ }^{7}$ Merleau-Ponty distingue entre linguagem falada, que é adquirida e desaparece diante do sentido do qual se tornou portadora, e linguagem falante, que se faz no momento da expressão e fará passar dos signos ao sentido
} 
sentido novo. Reconhecendo a fecundidade que a linguagem empírica oferece, Merleau-Ponty admite que exprimir-se criativamente implica munir-se de todos os instrumentos já falantes para fazê-los dizer algo que jamais disseram. Ele então interroga a literatura, nesse caso a literatura moderna $^{8}$, para lhe colocar uma questão cada vez mais filosófica. Assim, o filósofo francês se vale do romance e da poesia, porque portam expressões inovadoras, radicalizam e rompem com as formas convencionais pré-estabelecidas, exercitam uma linguagem sempre em estado nascente. A escrita literária é expressão, algo que não se deve confundir com mera "tradução de um pensamento" já dado, pois exprimir-se é criar, e a criação só pode se dar pelo enraizamento na experiência que o escritor realiza.

O escritor se coloca diante da língua disponível para metamorfoseá-la. Na verdade, ele se deixa envolver pela língua a ponto de ela habitar seus mais "secretos pensamentos" e ressignificálos em novas articulações de sentido, como se ela "fosse feita para ele, e ele para ela". Desse modo, habitando uma comunidade linguística e retomando uma tradição que a perpassa, o escritor traz à existência uma nova linguagem através da realização de sua obra poética ou literária, que é um "aparelho para criar significações" e secreta quase sempre uma significação inédita (MERLEAU-PONTY, 2012, p. 42).

Essa nova linguagem, em sua "função positiva e conquistadora", deixa de ser a serva das significações para se tornar “o ato mesmo de significar" (MERLEAU-PONTY, 1991, p. 263). Ela se manifesta no escritor em trabalho, justamente quando ele não se contenta, como mostra Mallarmé, "com a tagarelice cotidiana" ou com o "uso prosaico" ou corriqueiro, mas quando se volta à fala poética, inteiramente guiada pela própria linguagem, "sem referência direta ao próprio mundo, nem à verdade prosaica” (MERLEAU-PONTY, 2004, p. 64, tradução nossa). O escritor não se limita a reproduzir signos convencionais, mas busca a "grande prosa", que, para MerleauPonty (2000, p. 45), consiste na "arte de captar um sentido novo que nunca tinha sido objetivado até então e de torná-lo acessível a todos aqueles que falam a mesma língua”.

(MERLEAU-PONTY, 2012, p. 39). Essa linguagem falante possui um valor heurístico e uma função conquistadora, tornando-se a linguagem da literatura, do escritor em trabalho. Essa distinção equivale ao que Merleau-Ponty (1991, p. 45) chamou de "uso empírico da linguagem, já elaborada, e de uso criador, do qual o primeiro, aliás, só pode ser um resultado", é a linguagem autêntica.

${ }^{8}$ Essa escolha está mais evidenciada no meu artigo: A escolha de Merleau-Ponty pela escrita moderna de Valéry no curso Recherches sur l'usage littéraire du langage (SANTOS JÚNIOR, 2020). É importante ressaltar que Merleau-Ponty não abandona o discurso filosófico para fazer qualquer teoria estética ou literária. Pelo contrário, ao se aproximar desses domínios, colabora para a reformulação da linguagem da filosofia, marcada, em sua época, pela crise da razão. 
Recorrendo à obra de Proust, Merleau-Ponty (1968, p. 41, tradução nossa) admite que a palavra literária diz o mundo enquanto ele foi dado a viver por alguém, e "falar ou escrever pode tornar uma maneira de viver". E cabe à literatura "conquistar pelas palavras o contato mudo da percepção, da visão", tornar acessível aos outros este mundo sem familiaridade, essa experiência fundamental que é justamente "experiência correlativa do silêncio das coisas e da aparição da fala" (MERLEAU-PONTY, 2020, p. 137, tradução e grifo nossos). Desse modo, o ato de escrever não deixa de ser "traduzir uma experiência", mas não no sentido de uma transposição arbitrária de signos ou, então, como cópia, réplica de palavras de uma determinada situação. Na verdade, não sendo pura repetição, nem pura criação, "escrever é propriamente traduzir uma experiência, mas que só se torna texto através da palavra [parole] que ela suscita" (MERLEAU-PONTY, 1968, p. 41, tradução nossa, grifo do autor), simplesmente porque "as coisas apelam à palavra; o interior das coisas é palavra lateral, indireta" (MERLEAU-PONTY, 2020, p. 138, tradução e grifo nossos). E cabe ao escritor "produzir um sistema de signos que restitua por seu agenciamento interno a paisagem de uma experiência" ${ }^{9}$ ". Essa paisagem despertará as palavras para uma "sintaxe profunda", para um outro modo de "composição e de narrativa, que desfaçam e refaçam o mundo e a linguagem usuais" (MERLEAU-PONTY, 1968, p. 40, tradução nossa), tornando-os aptos a abrigá-los sob a forma de um texto, sempre aberto e acessível aos outros.

Assim, a experiência é este "livro interior" (MERLEAU-PONTY, 1968, p. 41, tradução nossa) que só se lê à medida que se lhe exprime ou cria. Criação e expressão, aqui, "são dois lados de uma mesma moeda, pois falar de criação é o mesmo que falar de expressão". Se devesse tudo à experiência, a expressão não seria criação, mas pura repetição; e, se prescindisse da experiência, a criação jamais seria expressão, mas pura inovação. Então, tem-se uma "expressão criativa e/ou criação expressiva", na qual a "experiência se exprime na criação e se cria na expressão" (OLIVEIRA, 2002, p. 98, grifo do autor). Assim, se a obra literária é criada, resta que essa criação não aconteça ex nihilo, mas que seja "criada enquanto coisa-dita, a partir do que o escritor vê"; o estilo é visão (MERLEAU-PONTY, 1996, p. 217, tradução nossa, grifo do autor).

\footnotetext{
${ }^{9}$ Traduzir a paisagem de uma experiência exige a função criativa da linguagem, pois a literatura dá a ver, por palavras, novas perspectivas de mundo ao invés de confirmar as que se tem disponíveis. "A escrita é invenção do mundo no duplo sentido do termo; ela o revela e o cria" (COLLOT, 1997, p. 34, tradução nossa).
} 


\section{A LITERATURA COMO OPERAÇÃO DE ESTILO}

A obra literária se engendra a partir da retomada de uma tradição linguística e da conversão em novas significações do que foi legado. Isso não significa que essa recapitulação da tradição se ofereça como captura de uma essência intocável, mas significa tê-la como uma quasepresença, como um livro que se metamorfoseou e que, no entanto, não deixou de manifestar sua verdade enquanto se expressa - verdade entendida aqui como sedimentação do sentido. A virtude que a palavra possui de criar e se cristalizar numa cultura não the garante o poder de eternizar-se enquanto verdade universal, pois uma obra literária jamais esgota todos os sentidos possíveis ao se expressar, e na linguagem, situada no mundo e aberta a ele, há uma impossibilidade que lhe é inerente de se esgotar numa totalidade de falas, significações, palavras, conceitos.

O escritor pode até ter a ilusão de que a realização de sua obra seja expressão de uma verdade que quer "ser integral", mas tal vontade de a obra totalizar-se ou encerrar-se esbarra no que Merleau-Ponty (2012, p. 175) chamou de "ductibilidade da fala", pois nada iguala à capacidade da linguagem em sua função plástica e elástica, a qual concentra e distende de diversos modos as significações e diferentes sentidos das palavras, instalando-se numa atmosfera de instabilidade, abertura e criação de novos sentidos. A presunção de uma dizibilidade total do real embasada na crença de uma linguagem que conseguiria abarcar todas as significações, todo silêncio, é nula, remete ao ideal de uma linguagem pura, que pressupõe uma coincidência entre a linguagem e seu referente exterior. Na verdade, Merleau-Ponty quer evidenciar a recusa de uma literatura que contenha, através do sistema linguístico, a verdade de toda a linguagem, como se ela pudesse ser esgotada. Por esse motivo, em geral, a literatura aceita mais resolutamente nunca ser total e oferece apenas significações abertas.

Na relação do escritor com sua língua, tudo que ele escreverá está por fazer-se no interior dessa língua na qual ele está instalado. Como "profissional da linguagem”, que só a compreende instalando-se nela e realizando-a, o escritor é também um "profissional da insegurança” porque deixa-se guiar pelo movimento da linguagem. O escritor não é senhor da linguagem, no entanto, ela nada pode sem ele, e sua operação expressiva ganha impulso a cada obra, pois cada obra é "um degrau construído por ele mesmo, sobre o qual se instala para construir com o mesmo risco um outro degrau", sendo a sua obra "a sequência dessas tentativas" (MERLEAU-PONTY, 1991, p. 263). Não existem poder e distância do escritor perante a linguagem; são, aqui, uma única e 
mesma coisa. O próprio escritor "é como um novo idioma que se constrói, inventa para si meios de expressão e diversifica-se segundo seu próprio sentido" (MERLEAU-PONTY, 2000, p. 45, tradução nossa). A linguagem de tal maneira o incorpora, tornando-se ele mesmo, pois não é outra coisa que ela faz senão prolongar em palavras a configuração da experiência esboçada no silêncio da vida perceptiva. Nesse sentido, toda produtividade da linguagem do escritor só se desvela ao leitor quando aquele se entrega a ela, recusando "pedir-lhe a todo instante justificações para seguila aonde ela vai”; essa linguagem, diz Merleau-Ponty (1991, p. 82), transporta o leitor, de "maneira imperiosa e breve e sem transições nem preparativos", do mundo estabelecido linguisticamente para o seu próprio mundo.

Por isso, na literatura, a virtude do escritor não reside no fato de comunicar verdades objetivas e ideias prontas, mas em seu estilo. Através do estilo, o escritor reinventa a linguagem, imprime-lhe uma torsão, reintroduz nela, assim como o pintor opera na pintura, uma deformação coerente. Disso decorre que, para Merleau-Ponty (2012, p. 158), o sentido de um romance só pode ser percebido como "uma deformação coerente imposta ao visível”, o que configura a concepção do romance como "operação de estilo", a qual exprime uma "significação oblíqua ou latente" (p. 155). Por outro lado, existe também o romance como relato de acontecimentos, como enunciado de ideias, significação prosaica. Merleau-Ponty contrasta os dois, sendo somente no primeiro caso — o romance como "operação de estilo" — que a narrativa se revela como "matriz de ideias", que "faz ver" com palavras, instala o leitor num mundo desconhecido ao qual ele não tem acesso (MERLEAU-PONTY, 2012, p. 157). Nessa literatura que é matriz de novas ideias, a fala do escritor ou seu estilo está acima da "técnica" ou do "instrumento". Não está a serviço de uma finalidade exterior, pois tem em si mesma sua regra de emprego, sua moral, sua visão de mundo; ou seja, essa literatura dá um ponto de vista sobre o mundo, oferece uma perspectiva sobre as coisas, ou mais ainda, “dispõe nas coisas um relevo" (MERLEAU-PONTY, 1968, p. 40, tradução nossa), revelando um mundo inaugural ainda por falar.

O livro, diz Merleau-Ponty, é uma máquina infernal de produzir significações, e sua virtude, por meio da capacidade da linguagem, é cativar o leitor, de modo que ele não vê mais letras sobre o papel, nem se atém aos sinais, mas participa de uma aventura que é pura significação e, no entanto, o escritor não poderia se oferecer aos leitores senão como linguagem. Para o filósofo francês, o triunfo da linguagem é de fazer crer, ao término da leitura de um livro, que o leitor se comunica com o autor, "sem ter dito palavra alguma, de espírito a espírito" (MERLEAU-PONTY, 2012, p. 39-42, passim). Entre o escritor e o leitor há cumplicidade, pois, 
ao iniciar a leitura de um livro, o leitor preguiçosamente acredita contribuir com algum pensamento, compreende a escrita porque ambos vivem na mesma língua, possuem o mesmo repertório de signos, experiências, depositados pela cultura e sedimentados no mundo de ambos.

Entretanto, de repente, algumas palavras "pegam". O escritor as desviou de seu sentido costumeiro e elas arrastam o leitor, como num turbilhão, para um sentido novo, que se alcança graças a elas. Para exemplificar, Merleau-Ponty (2012, p. 41-42) escreve: "sei, antes de ler Stendhal, o que é um patife, e posso portanto compreender o que ele quer dizer quando escreve que o fiscal Rossi é um patife. Mas quando o fiscal Rossi começa a viver, não é mais ele que é o patife, é o patife que é um fiscal Rossi”. Acontece que, diz Merleau-Ponty, o escritor me invade, passo a pensar de dentro dele e não apenas com ele. Ele se pensa em mim, “"nesse instante ao menos fui você'. Crio Stendhal, sou Stendhal ao lê-lo, mas isso porque primeiro ele soube instalar-me dentro dele". O leitor que parecia dominar o livro, na verdade é apossado por ele, e o livro o obriga a ir além dos signos corriqueiros e perceber uma linguagem falante. Quando isso acontece, tem-se a sensação de que houve comunicação, pois não há como distinguir as palavras do escritor e as do leitor. Nesse momento, uma aquisição foi feita, e Stendhal, por exemplo, agora poderá ser lido e pertencerá às significações disponíveis da cultura. E mais, se quem o ler for escritor, isto é, "capaz de encontrar as elipses, as elisões, as cesuras da conduta, [...] responderá à convocação e se reunirá a ele no centro do mundo imaginário que ele governa e anima" (MERLEAU-PONTY, 2012, p. 155).

Portanto, Merleau-Ponty nomeia a obra literária como "operação de estilo" simplesmente porque ela é o resultado de um "sistema de palavra" que se constitui, pelo exercício do estilo, durante toda a vida de escritor na sua lida com a linguagem. O estilo do escritor se revela indiretamente quando ele deforma a linguagem e faz surgir uma linguagem tácita, plena de silêncio, lá onde diz quando parece nada dizer; é do não dito, das suas faltas ou de seus desvios, que o estilo é feito e se manifesta no escritor. Por essa razão, toda história de Stendhal é também aquela de um "aprendizado da fala", da própria linguagem, que lhe permite fazer-se presente no mundo e aos outros. Stendhal ou qualquer escritor se torna capaz de, "pelo exercício da vida e do estilo", sair de sua separação entre homem e autor, vida e obra, e transformar em "motivos de vida" até suas "dificuldades de ser" e construir "uma vida como uma obra" (MERLEAUPONTY, 1968, p. 28-30, passim, tradução nossa). Então, o escritor faz de sua profissão uma tarefa fatigante e interminável, assim como sua obra, que é expressão desse estilo, mas que nunca está encerrada. Quer dizer, uma obra realizada jamais poderá existir em si mesma como coisa 
pronta, fechada sobre sua própria significação, cabendo ao leitor decodificá-la, mas é aquela que se dá ao leitor, segundo o estilo que lhe é próprio, como incitação para que ele retome o gesto que a criou (MERLEAU-PONTY, 1991, p. 52).

Sendo assim, o leitor passa a habitar o mundo do escritor, graças ao fascínio da linguagem que é o solo comum. O leitor precisa ultrapassar-se pela leitura e se deixar interpelar, transformarse pelo livro, e adquire, graças ao próprio livro, "novos órgãos" de expressão. Disso decorre a importância que a literatura como operação de estilo assume no pensamento de Merleau-Ponty, pois, mais do que conter ideias, ela é matriz de novas ideias, cujo sentido "nunca terminamos de desenvolver" (MERLEAU-PONTY, 1991, p. 81), cuja função é ser tão "singular e inesgotável quanto uma coisa vista" (MERLEAU-PONTY, 2012, p. 38). Uma vez escrito, se a expressão foi "bem-sucedida", o livro presumivelmente se universaliza - não o universal do conceito puro, idêntico em todos os espíritos - , numa universalidade de uma significação acessível a todos, que se define a partir da relação do leitor que a acolhe, passando a ser, daí em diante, "este apelo que um pensamento situado endereça a outros pensamentos igualmente situados" (MERLEAUPONTY, 2000, p. 44, tradução nossa). Então, se assim acontece, a obra literária só pode ser caracterizada como uma instituição, uma vez que a instituição, enquanto matriz simbólica, abre um campo, um porvir, torna-se "o estabelecimento, em uma experiência, de dimensões em relação às quais toda uma série de outras experiências terão sentido, ela inaugura uma história" (MOURA, 2012, p. 104).

\section{A MATRIZ TEMPORAL E HISTÓRICA DA INSTITUIÇÃO}

Na conclusão do texto "A linguagem indireta e as vozes do silêncio", Merleau-Ponty reforça a questão da relação entre a pintura e o signo, pois tratar a pintura como linguagem é demonstrar como um "sentido perceptivo" pode "recolher numa eternidade sempre por refazer uma série de expressões anteriores” (MERLEAU-PONTY, 1991, p. 79). Quer dizer, a pintura retoma uma tradição e, a partir dela, institui um novo sentido na cultura. Dessa maneira, ao alicerçar as expressões artísticas na noção de diacriticidade, Merleau-Ponty atribui à pintura e à literatura a tarefa de recriarem a partir do passado e ultrapassarem na direção do futuro, reabrindo a história e a cultura por meio da capacidade de instituição e reativação do sentido. Para isso, ele se vale da noção husserliana de Stiftung e opera uma transformação de sua reflexão ao admitir a instituição como abertura temporal, advento, mas que, diferentemente de Husserl, não necessita 
retornar ao cogito reflexivo ou a uma consciência intelectualista para estabelecer a clareza da linguagem.

Merleau-Ponty (2012, p. 124) escreve em A prosa do mundo:

\begin{abstract}
Husserl empregou a bela palavra Stiftung para designar a princípio essa fecundidade indefinida de cada momento do tempo que, justamente por ser singular e por passar, jamais poderá deixar de ter sido ou de ser universalmente - e, mais ainda, a fecundidade, derivada dessa, das operações da cultura que inauguram uma tradição, que continuam a valer após seu aparecimento histórico e exigem, para além delas mesmas, operações diferentes e as mesmas.
\end{abstract}

O passado da pintura cria para o pintor uma tradição, aquilo que Husserl chamou de esquecimento das origens, e o pintor retoma esse passado, não para lhe dar uma sobrevida, que é a forma hipócrita do esquecimento, mas para demonstrar a eficácia dessa retomada, que é forma nobre da memória. Isso só é possível porque a presença da instituição é comparável à presença do tempo, porque “o tempo é o modelo da instituição" (MERLEAU-PONTY, 2015b, p. 47, tradução nossa); ela não submete o tempo à necessidade de uma consciência sobre ele, tampouco o rejeita como se fosse algo isolado em si mesmo. A instituição possui uma nervura temporal própria, cuja temporalidade não se restringe à sensorialidade corporal, mas advém de uma camada anterior a esta, pois está na gênese do próprio Ser e pode ser designada como nascimento, diferença, gênese continuada cuja sequência não está pré-determinada. Em seu curso sobre a L'institution, la passivité (1954-1955), Merleau-Ponty (2015b, p. 162, tradução nossa) entende por instituição “os acontecimentos de uma experiência que a dotam de dimensões duráveis, em relação às quais toda uma série de outras experiências terão sentido, formarão uma sequência pensável ou uma história”. Isto é, a noção de instituição destaca sua abertura, sua historicidade, porque não é, na verdade, definida por si mesma, mas pelas suas sequências. Em outras palavras, há uma dialética entre a instituição e sua sequência porque ela dá um sentido à sua sequência, confere-lhe unidade e esta, por conseguinte, realiza seu sentido.

A instituição tem o poder de evocação, é como guia para o pensamento, e a tarefa do filósofo, do escritor, de maneira geral, é explorar esse campo aberto por ela a fim de lhe dar coerência no seio da experiência sensível. A partir desse campo histórico, pode-se pensar tanto a história de um vivente quanto a história do ser humano, a história da arte, da literatura. Uma história aberta e cujo espírito não é inapreensível e celeste, mas feito do estofo do mundo, daquilo que se fala, se escreve e se pinta. 
Nessa perspectiva, a instituição também incorpora os ganhos da noção de diacriticidade, visto que o advento de uma significação latente pede sua sequência, e é capaz de, ao mesmo tempo, recuperar e ultrapassar significações anteriores e de apelar a novas criações de sentido por uma retomada posterior. Por exemplo, "o pintor aprende a pintar de outro modo imitando seus antecessores. Cada uma de suas obras anuncia as seguintes - e faz com que não possam ser semelhantes. Tudo se encaixa e, no entanto, ele não saberia dizer para onde vai” (MERLEAUPONTY, 1968, p. 63, tradução nossa). Há aqui, não uma relação de causa e efeito, nem a redução da obra à vida, mas uma verdadeira reversibilidade entre o instituinte e o instituído, entre o dado e o criado, como num movimento dialético entre o mundo sensível e o mundo expressivo. Por isso, como bem observa Chauí (2009, p. 30), a instituição será sempre abertura de campos, seja na Natureza e na Cultura, o que significa, primeiramente, que, nesta, a oposição entre exterioridade e interioridade ou entre o em-si e o para-si é desfeita e, ao mesmo tempo, consequentemente, modifica relação do sujeito com o mundo, deixa de se apresentar como presença imediata para surgir como abertura, perspectiva, configuração.

Por exemplo, se se pensa a literatura enquanto instituição, observa-se que a força de sua linguagem reside inteiramente no tempo presente, nem no porvir da intelecção, nem no passado mítico, dando a ilusão de ultrapassar toda fala e de ir às próprias coisas, porque ultrapassa sempre a linguagem dada. Nesse ultrapassamento, algo foi adquirido, fundado para sempre e poderá ser transmitido, assim como os atos expressivos passados o foram, não porque se teria apreendido parte do mundo inteligível ou atingido o pensamento adequado, mas porque o uso presente da linguagem poderá ser recuperado enquanto a mesma língua estiver disponível ou enquanto estudiosos forem capazes de recolocá-la no presente (MERLEAU-PONTY, 2012, p. 84).

Graças aos atos expressivos, ou seja, pela virtude e força que a expressão contém, há a incorporação de um passado no presente e abertura a um futuro ao criar um saber adquirido "para sempre". Esses atos contribuem para cumprir o voto de recuperação do mundo que foi pronunciado com o aparecimento de uma língua, de um sistema de signos que pretendia abarcar qualquer ser que se apresentasse, o que é impossível. No momento em que algo foi fundado em significação, uma experiência foi transformada em seu sentido, tornou-se verdade, significação que se instalou no sujeito. Ao passo que a expressão "bem-sucedida" encontra um projeto antigo e liberta o que estava cativo no ser desde sempre, estabelece na espessura do tempo pessoal e interpessoal uma comunicação interior pela qual o presente se torna a verdade de todos os outros acontecimentos; pois, como diz Merleau-Ponty (1991, p. 103), “a verdade é um outro nome da 
sedimentação, que por vez é a presença de todos os presentes no nosso". Resta saber como a obra de arte opera essa retomada da tradição e institui um novo sentido na história como advento, abertura inesgotável.

\section{HISTÓRIA DA OBRA DE ARTE COMO PROMESSA DE ADVENTOS}

Em seu curso L 'institution, la passivité, Merleau-Ponty insiste no caráter histórico e aberto da obra de arte. Para ele, o sentido que ela institui é externo e só existe graças a um "sentido interno à obra, que é sempre aberto, distanciamento em relação a uma norma de sentido, diferença", ou seja, o sentido emerge diacriticamente da relação que há entre o interior e exterior da obra (MERLEAU-PONTY, 2015a, p. 53, grifo do autor). Por isso, na literatura, na pintura, o sentido da obra está sempre no interior das coisas, na experiência pré-linguageira do mundo e, por conseguinte, retoma uma tradição mais antiga do que ela, a do mundo perceptivo tal como a pintura revela, e cria uma nova, a da obra da cultura. Retomar uma tradição não significa submeter-se a ela como história linear de acontecimentos, mas significa admitir essa abertura que institui a história cultural num horizonte prático. Como se vê nas palavras de Merleau-Ponty (1968, p. 50, tradução nossa): "nosso contato com nosso tempo é uma iniciação a todos os tempos, o homem é historiador porque é histórico, a história não é senão a ampliação da prática".

Sendo assim, cada obra de arte recupera as obras dos outros e do próprio artista, do escritor numa espécie de "eternidade provisória," como "resposta àquilo que o mundo, o passado, as obras feitas reclamavam" (MERLEAU-PONTY, 1991, p. 61). Na literatura, por exemplo, o escritor não se contenta somente em continuar a língua, ele instaura uma nova tradição: abre o tempo e a história incidindo sobre questões que o presente lhe apresenta, resgatando o passado ao criar o que virá. Com sua obra, o escritor introduz uma nova coerência e um novo equilíbrio naquilo que existia antes dele, o mundo cultural, para que este depois seja retomado como expressão que contém a falta e o excesso do que se deseja exprimir. Não há mais separação ou oposição entre o presente como simultaneidade e o tempo como mero escoamento, e sim quiasma, no qual se está mergulhado, segundo Chauí (2002, p. 191, grifo da autora), numa "totalidade simultânea", numa abertura, visto que o tempo, "como vazio determinado e excesso", reclama um porvir, exige um futuro, uma sequência, não como finalidade, mas como restituição instituinte do passado. 
Então, Merleau-Ponty (2012, p. 131-132) recorre à história das obras de arte para apresentar duas historicidades: "historicidade da morte" e "historicidade da vida". A primeira é história empírica dos acontecimentos, é linear, "irônica", “irrisória”, feita de contrassensos, "é antes esquecimento do que memória, é fragmentação, ignorância, exterioridade"; a segunda, sem a qual a primeira seria impossível, é história de adventos, "constituída e reconstituída pouco a pouco pelo interesse que nos dirige para o que não é nós, por essa vida que o passado, numa troca contínua, nos traz e encontra em nós” (MERLEAU-PONTY, 1991, p. 62, grifo do autor), e que permanece em cada ato criador que retoma e relança a cada nova obra o empreendimento inteiro do passado.

Sob esse aspecto, Merleau-Ponty diz que "a função do Museu, como a da Biblioteca," por um lado, é reunir as obras, como momentos de um único esforço, dando a impressão de que elas estão ali encerradas e existem para serem contempladas, e que a unidade histórica se faz por meio de acumulação e agrupamento de obras; por outro, ambos substituem a história como advento pela pomposa história oficial e celebrativa, cujo resultado é o esquecimento e a perda da forma nobre da memória (MERLEAU-PONTY, 1991, p. 61-63). O Museu e a Biblioteca inspiram uma má consciência histórica, "uma consciência de ladrões", porque transformam as obras em obras, fazem aparecer os estilos, "mas acrescentam também, ao verdadeiro valor delas, um falso prestígio, separando-as das vicissitudes em meio às quais nasceram, fazendo-nos crer que Sobreartistas, 'fatalidades' guiavam a mão dos artistas desde sempre”. Com isso, desconsideram a pulsação vital que faz com que as obras apareçam e as transformam em "prodígios de outro mundo". Por isso faz todo sentido Merleau-Ponty afirmar que "o Museu mata a veemência da pintura assim como a Biblioteca, dizia Sartre, transforma em mensagens os escritos que eram gestos de um homem...” (MERLEAU-PONTY, 2012, p. 131-132, grifo do autor).

No entanto, a conservação dessa historicidade pudica, morta, que o Museu e a Biblioteca patenteiam, não elimina a historicidade da vida contida na obra. Uma não existe sem a outra. Nesta última, o pintor e o escritor, por um só gesto, retomam a tradição instituída, sem ter que abandonar seu tempo, seu lugar. Isso permite a essa historicidade manter viva a fecundidade do tempo, colocando as obras de arte inteiramente no presente, habitando os artistas e reintegrandoos à fraternidade dos pintores e escritores, conservando a história como promessa de adventos. E o advento é o excesso da obra sobre as intenções significativas do artista, é o não realizado da obra deixado pelo escritor, pelo pintor e que, no interior das obras, é experimentado como falta para ser retomado pelos que virão. 
Merleau-Ponty propõe que toda "ordem da cultura ou do sentido" deve ser reconhecida como "ordem original do advento", quer dizer, não deve ser derivada de puros acontecimentos, nem tratada como simples causalidade temporal. Todavia, o advento não dispensa os acontecimentos, pois, como ele afirma, "não há, acima dos acontecimentos, uma segunda causalidade que faria do mundo da pintura um outro mundo suprassensível, com suas leis próprias" (MERLEAU-PONTY, 2012, p. 143), porque assim se cairia no erro de postular uma eternidade ou um Espírito que se possuiria no avesso do mundo e se manifestaria aos poucos. Nesse caso, distinguir a ordem do acontecimento da do advento não conduz a esse erro. Pelo contrário, faz com que cada obra de arte abra um horizonte de pesquisa ao passo que torna possível o que não existia antes dela, bem como quando transfigura o seu passado histórico ao mesmo tempo que o realiza. Somente assim pode-se compreender o sentido da obra de arte como gênese contínua, como fruto do trabalho do artista ou do escritor, em que vida e obra não se separam; e o advento, "que não é um ultrapassar do tempo", como "promessa de acontecimentos" ${ }^{10}$ (MERLEAU-PONTY, 2012, p. 146).

Essa historicidade fecunda do advento é a certeza de que a obra de Stendhal será lida em cem anos, permanecendo inesgotável de sentido e sendo nada mais do que a realização de uma verdade que se sedimentou e que adquiriu sua força no presente. Ademais, ela significa que a obra mantém viva a intersubjetividade entre escritor e leitor, a capacidade de instalar o leitor em vidas que não são as dele, confrontando-as, fazendo-o responsável por todas elas.

Portanto, nisto consiste o mistério da expressão, qual seja, o de nunca abandonar a espontaneidade da linguagem, de confiar a ela a tarefa de recolher o sentido em estado nascente, nas próprias coisas, de sublimar uma experiência sensível que na percepção e na memória está condenada a se perder. Esse sentido que desvela as articulações da experiência sensível e afetiva que o sujeito exerce com o mundo se realiza na escrita quando o escritor busca apresentar a coesão dessa experiência primitiva do mundo e desenvolver o texto interior que a experiência do mundo nele imprimiu. Somente assim, enquanto linguagem e cada um a seu modo, a pintura e a literatura contribuem para "fazer a cultura tácita sair de seu círculo mortal” (MERLEAU-PONTY, 1991, p. 83), isto é, ressignificam o aparecer das artes numa cultura, bem como sua relação com o

10 "O advento é aquilo que, do interior da obra, clama por uma posteridade, pede para ser acolhido, exige uma retomada porque o que foi deixado como herança torna-se doação, o dom para ir além dela. Há advento quando há obra e há obra quando o que foi feito, dito ou pensado dá a fazer, dá a dizer, dá a pensar.” (CHAUÍ, 2002, p. 192, grifos da autora). 
passado. De modo que literatura e pintura renunciam a qualquer "eternidade hipócrita da arte" para enfrentar o tempo, revelando-o ao invés de evocá-lo vagamente, surgindo vitoriosas sobre o tempo ao fundá-lo em significação. Assim, elas se mostram capazes de conquistar possibilidades ainda não exploradas na linguagem, "fazendo ver" através das palavras o laço que o sujeito mantém com o mundo, com as coisas, além de oferecer à filosofia um reaprendizado da visão, do modo de acessar o real, que consiste em saber que "a vida pessoal, a expressão, o conhecimento e a história avançam obliquamente, e não em linha reta para os fins ou para os conceitos" (MERLEAU-PONTY, 1991, p. 88).

\section{REFERÊNCIAS}

BARBARAS, Renaud. Le tournant de l'expérience. Paris: VRIN, 1998.

CARBONE, Mauro. La visibilité de l'invisible. Merleau-Ponty entre Cézanne et Proust. Hildesheim: Georg Olms Verlag, 2001.

CHAUI, Marilena. Da constituição à instituição. Cadernos espinosanos XX, São Paulo, n. 20, p. 11-36, 2009.

CHAUI, Marilena. Experiência do pensamento: ensaios sobre a obra de Merleau-Ponty. São Paulo: Martins Fontes, 2002.

COLLOT, Michel. L'ouevre comme paysage d'une experience. In: CASTIN, Nicolas; SIMON, Anne (org.). Merleau-Ponty et le littéraire. Paris: Presses de l'ENS, 1997. p. 23-37.

MERLEAU-PONTY, Maurice. Conversas - 1948. Tradução Fábio Landa e Eva Landa São Paulo: Martins Fontes, 2004.

MERLEAU-PONTY, Maurice. Fenomenologia da percepção. Tradução Carlos A. de Moura. 4. ed. São Paulo: Martins Fontes, 2015a.

MERLEAU-PONTY, Maurice. L'institution, la passivité: notes de cours au Collège de France (1954-1955). Paris: Belin, 2015b.

MERLEAU-PONTY, Maurice. Le monde sensible et le monde de l'expression. Avant-propos Emmanuel de Saint-Aubert. Cours au Collège de France Notes, 1953. Genève: MetisPresses, 2011.

MERLEAU-PONTY, Maurice. Notes de cours au Collége de France 1958-1959 et 1960-1961. Paris: Gallimard, 1996.

MERLEAU-PONTY, Maurice. Parcours deux. Lagrasse: Verdier, 2000. 
MERLEAU-PONTY, Maurice. Le problème de la parole. Avant-propos Lovisa Andén. Postface Franck Robert. Cours au Collège de France Notes, 1953-1954. Genève: MetisPresses, 2020.

MERLEAU-PONTY, Maurice. A prosa do mundo. Tradução Paulo Neves. São Paulo: Cosac \& Naify, 2012.

MERLEAU-PONTY, Maurice. Recherches sur l'usage littéraire du langage. Avant-propos Benedetta Zaccarello.Cours au Collège de France Notes, 1953. Genève: MetisPresses, 2013.

MERLEAU-PONTY, Maurice. Résumés de cours: Collége de France 1952-1960. Paris: Gallimard, 1968.

MERLEAU-PONTY, Maurice. Signos. Tradução Maria Ermentina G. Gomes Pereira. São Paulo: Martins Fontes, 1991.

MOURA, Carlos Alberto Ribeiro. Merleau-Ponty leitor dos clássicos. Doispontos. Curitiba, São Carlos, v. 9, n. 1, p. 97-119, 2012.

OLIVEIRA, Wanderley Cardoso de. Expressão e filosofia em Merleau-Ponty. 2002. 205f. Tese (Doutorado) - Instituto de Filosofia e Ciências Sociais, Universidade Federal do Rio de Janeiro, Rio de Janeiro, 2002.

ROBERT, Franck. Vers l'ontologie (Postface). In: MERLEAU-PONTY, Maurice. Le problème de la parole. Avant-propos Lovisa Andén. Cours au Collège de France Notes, 1953-1954. Genève: MetisPresses, 2020. p. 239-265.

SANTOS JÚNIOR, Iracy Ferreira. A escolha de Merleau-Ponty pela escrita moderna de Valéry no curso Recherches sur l'usage littéraire du langage. Inconfidentia. Mariana, v. 4, n. 8, 2020, p. 57-72.

WALDENFELS, Bernhard. Fait voir par les mots: Merleau-Ponty et le tournant linguistique. In: Merleau-Ponty l'héritage contemporain. Chiasmi International, v. I. Paris: VRIN, 1999. p. 5763. 